\title{
1 Origin and radiative forcing of black carbon aerosol: production
}

\section{2 and consumption perspectives}

3 Jing Meng ${ }^{1,2,3}$, Junfeng Liu ${ }^{2, *}$, Kan $\mathrm{Yi}^{2}$, Haozhe Yang ${ }^{2}$, Dabo Guan ${ }^{4, *}$, Zhu Liu ${ }^{5}$, Jiachen

4 Zhang ${ }^{6}$, Jiamin $\mathrm{Ou}^{4}$, Stephen Dorling ${ }^{7}$, Zhifu Mi ${ }^{8}$, Huizhong Shen ${ }^{2}$, , Qirui Zhong ${ }^{2}$, and

5 Shu $\mathrm{TaO}^{2}$

61 Department of Politics and International Studies, University of Cambridge, Cambridge CB3

7 9DT, UK

82 Laboratory for Earth Surface Processes, College of Urban and Environmental Sciences, Peking

9 University, Beijing, China

103 Department of Land Economy, University of Cambridge, Cambridge, CB3 9EP, UK

114 Water Security Research Centre, School of International Development, University of East Anglia, 12 Norfolk, United Kingdom

135 Tyndall Centre for Climate Change Research, School of International Development,

$14 \quad$ University of East Anglia, Norwich NR4 7JT, UK

156 Department of Civil and Environmental Engineering, University of Southern Los Angeles, CA, 16 USA

177 School of Environmental Sciences, University of East Anglia, Norfolk, United Kingdom

188 Bartlett School of Construction and Project Management, University College London, London 19 WC1E 7HB, UK

* Corresponding authors:

23 jfliu@pku.edu.cn (Junfeng Liu) 


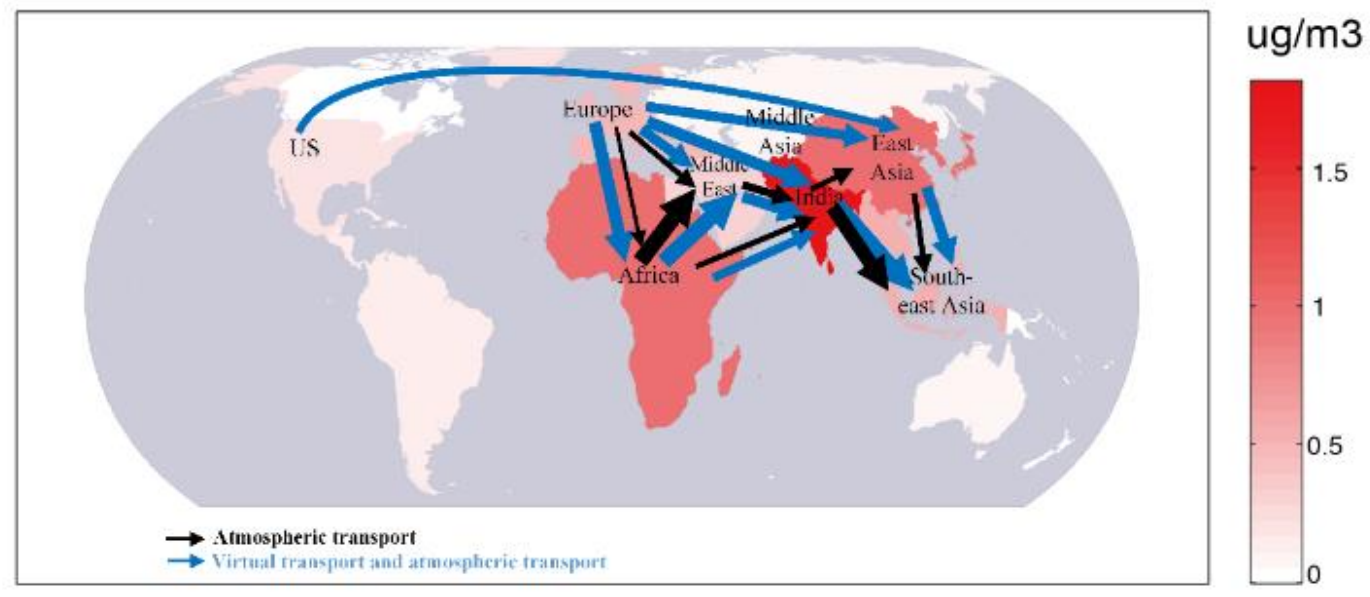

Air pollution, a threat to air quality and human health, has attracted ever-increasing attention in recent years. In addition to having local influence, air pollutants can also travel the globe via atmospheric circulation and international trade. Black carbon $(\mathrm{BC})$, emitted from incomplete combustion, is a unique but representative particulate pollutant. This study tracked down the $\mathrm{BC}$ aerosol and its direct radiative forcing to the emission sources and final consumers using the global chemical transport model (MOZART-4), the rapid radiative transfer model for general circulation simulations (RRTM) and a multiregional input-output analysis (MRIO). BC is physically transported (i.e., atmospheric transport) from western to eastern countries in the mid-latitude westerlies, but its magnitude is near an order of magnitude higher if the virtual flow embodied in international trade is considered. The transboundary effects on East and South Asia by other regions increased from about 3\% (physical transport only) to $10 \%$ when considering both physical and virtual transport. The influence efficiency on East Asia is also large because of the comparatively large emission intensity and emission-intensive exports (e.g., machinery and equipment). The radiative forcing in Africa imposed by consumption from Europe, North America and East Asia $\left(0.01 \mathrm{Wm}^{-2}\right)$ was even larger than the total forcing in North America. Understanding the supply chain and incorporating both atmospheric and virtual transport may improve multilateral cooperation on air pollutant mitigation both domestically and internationally.

Key words: black carbon, long-range transport, multiregional input-output analysis, radiative 


\section{Introduction}

Air pollution, especially in developing countries, has attracted ever increasing attention because of its substantial influence on air quality ${ }^{1}$, climate ${ }^{2}$ and human health ${ }^{3}$,

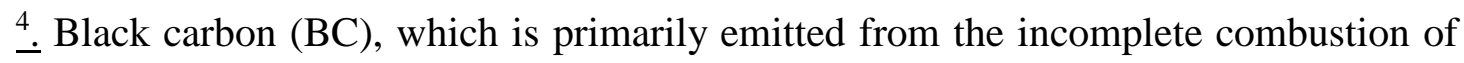
fossil fuels and biomass, is considered to be a valuable indicator and universal carrier for a broad category of short-lived combustion particles, such as sulfate, organic matter and trace metal ${ }^{5}, \underline{6}$. By absorbing solar radiation and reducing surface albedo, BC profoundly enhances global warming ${ }^{\underline{7}}$. The total climate forcing of $\mathrm{BC}$ is assessed to be $1.1 \mathrm{Wm}^{-2}$ in a recent study, which is second only to $\mathrm{CO}_{2}{ }_{-}^{8}$. Some States in the U.S. have included black carbon emissions and corresponding reduction strategies in their Climate Action Plans ${ }^{9}$. Additionally, evidence from epidemiological studies has shown a more robust association of increased human mortality with $\mathrm{BC}$ exposure than with total particle mass

Air pollution is typically regarded as a local problem because of short atmospheric lifetime, and source emission abatement measures are used to control emissions from power generation or industries within a territory ${ }^{14}$. However, air pollutants can travel a long distance via atmospheric movement $\frac{15-17}{}$. Both observational and modelling studies have shown that local air quality can be strongly affected by air pollutants from distant sources $\frac{18-20}{}$. In the recent years there has been increased attention in the aerosol research community about the potential effects of international trade on air pollutant emissions ${ }^{21}$, health effects $\underline{22}$ and radiative forcing. $\underline{23}$. However, previous studies either traced the BC transport to the original emission source regions $\underline{12,14-17}$ or tele-connected local emissions to global consumers $\underline{21,24-26}$. The atmospheric transport of air pollutants from the emitters to polluted regions and the virtual transfer from final consumers to emitters both are part of the supply chain. ${ }^{27}$ Few studies have linked the final consumers to those who ultimately suffer from except two studies on Eastern Asia $\underline{28}, \underline{29}$. This lack may impede progress towards international cooperation on air pollutant mitigation involving various parties through the supply chain. Tracking the entire supply chain from the final consumer through international trade and atmospheric transport to the health and 
climate endpoints in the polluted region creates opportunities for joint mitigation involving the final consumers, emitters and local regulators.

With a newly developed $\mathrm{BC}$ emissions inventory ${ }^{30}$ and tagging technique in the improved MOZART-4 which optimizes the aging timescale for each source region $\frac{17}{}$, we quantify the source-receptor relationship, in which BC aerosols emitted from 13 independent source regions are tagged and explicitly tracked from their source region. Then, these emissions are tele-connected to the final consumers using a fully coupled multiregional input-output (MRIO) model constructed from the Global Trade Analysis Project (GTAP) database, which has been widely employed to study the virtual transport of energy, land use, GHGs, water and so on $\frac{31-41}{}$. The details of our interdisciplinary approach and the underlying data are described in Methods.

\section{Methods}

\subsection{Model description and configuration}

In this study, atmospheric BC transport was simulated using the Model for Ozone and Related Chemical Tracers, version 4 (MOZART-4), which is an offline global chemical transport model developed by the National Center for Atmospheric Research $(\mathrm{NCAR})^{42}$. MOZART-4 resolves horizontal and vertical transport based on a chemical mechanism including 85 gas-phase species, 12 bulk aerosol compounds, and 39 photolysis and 157 gas-phase reactions, building on the framework of the Model of Atmospheric Chemistry and Transport (MATCH) with a series of updates $\underline{43}$. Horizontal transport is characterized by a semi-Lagrangian advection scheme $\underline{44}$ with a pressure fixer $\stackrel{45}{ }$. Vertical transport incorporates diffusion in the boundary layer $\frac{46}{6}$ and convective mass flux using a shallow and middle convection transport formulation ${ }^{47}$ and a deep convection scheme $\frac{48}{}$. In the standard model, BC is in a combination of hydrophobic $(80 \%)$ and hydrophilic forms $(20 \%)^{49}$. Hydrophobic BC is converted to hydrophilic BC with an exponential ageing timescale of $\sim 1.6$ days $\underline{50}, \underline{51}$. We improved the ability of the standard MOZART-4 model to predict concentrations of black carbon by optimized 
BC's ageing timescales and deposition rates in various regions, building on our previous work $\frac{17}{}$.

The model is run at a horizontal resolution of approximately $1.9^{\circ} \times 1.9^{\circ}$ (latitudexlongitude), with 28 vertical levels, and is driven by NCEP reanalysis meteorology. Anthropogenic BC emissions are developed by researchers at Peking University (PKU-BC 2011) $)^{30}$ based on a global $0.1^{\circ} \times 0.1^{\circ}$ fuel combustion dataset (PKU-FUEL-2011 covering 64 fuel combustion processes) ${ }^{52}$ and an updated emission factor $\mathrm{BC}\left(\mathrm{EF}_{\mathrm{BC}}\right)$ dataset ${ }^{5}$. Biomass burning emissions are acquired from the Global Fire Emissions Database (GFED) version $3 \frac{53}{3}$. We conducted one model simulation with tagging technology from 1 January 2010 to 31 December 2011. The first two years of the simulations are discarded as model spin-up.

\subsection{The source-tagging method}

There are different modelling approaches to quantify the contribution of a specific source region to aerosol in receptor regions; of these, the emission sensitivity approach has been widely used ${ }^{54-55}$. We have implemented a direct source region tagging technique in MOZART-4 that enables the derivation of aerosol source-receptor relationships without perturbing emissions. Tagging is more accurate than the emission sensitivity approach which relies on a set of model simulations with emission perturbations in the source regions as well as responses in the receptor regions and is not constrained by computational resources $\frac{15}{}$. Tagging technology has been increasingly used to quantify source contributions of air pollutants $\frac{56-57}{}$. In this study, we add 13 tracers to the model to explicitly track BC emissions from non-overlapping geopolitical regions, which are defined in Zhang et al. ${ }_{\rightarrow}^{17}$, to distinguish the differences in economies and emission source types between regions. The tagged source regions are Canada (CA), North America except Canada (NA), East Asia (EA), the former Soviet Union (SU), Europe (EU), Africa (AF), South America (SA), the Indian subcontinent (IN), Australia (AU), Middle Asia (MA), Southeast Asia (SE), the Middle East (ME), and the remaining regions (RR), as shown in Table S1 and Figure S1. For 
each simulation, the tagged tracers undergo transport and deposition processes in the same way as the untagged BC. Since all of the chemical and physical processes involving $\mathrm{BC}$ are nearly linear in MOZART-4, the sum of the 13 regional $\mathrm{BC}$ tracers is approximately equal to that of the untagged $\mathrm{BC}^{17}$.

In the MOZART-4 model, the hygroscopicity of BC-containing particles is a critical parameter, determining whether BC can be wet scavenged, and thus affects the lifetime and transport pathway of $\mathrm{BC}$. The hygroscopicity of $\mathrm{BC}$ is determined by two parameters controlling (1) the initial fraction of hydrophilic BC in freshly emitted BC (20\%), and (2) an e-folding ageing timescale, which characterizes the timescale for conversion of hydrophobic $\mathrm{BC}$ to hydrophilic $\mathrm{BC}$ in the atmosphere. It is essential to constrain the ageing timescale to accurately simulate long-range transport and the atmospheric concentrations of BC. Building on our previous study $\frac{17}{}$, we assign an ageing timescale for each source region, which is optimized by minimizing errors in the vertical profiles of BC mass-mixing ratios between simulations and HIAPER Poleto-Pole Observations (HIPPO). In general, the modelled surface concentration agreed within a factor of 2 with the observations (as shown by Figure S2).

We then use the following indicators to quantify the source-receptor relationships in atmospheric transport and to quantify the influence efficiency of $\mathrm{BC}$ in source region $i$ affecting $\mathrm{BC}$ surface concentration in receptor region $j$ :

As the fractional contribution of source region $i$ to aerosol property A (such as average surface concentration) in receptor $j$, following previous studies $\underline{15}, \underline{20}, \underline{58}, C_{\mathrm{i}, \mathrm{j}}$ is defined as

$$
C_{i, j}=\frac{\sum_{h=1}^{k} W_{i, j, h} \cdot S_{h}}{\sum_{h=1}^{k} \sum_{i}^{13} W_{i, j, h} \cdot S_{h}}
$$

where $W_{i, j, h}$ is the surface $\mathrm{BC}$ concentration in grid box $\mathrm{k}$ in receptor $j$ from source region $i, \mathrm{~S}_{h}$ is the area of grid box $h . k$ is the total grid boxes covered by region $j$.

The influence efficiency $\left(E F_{i, j}\right)$ of source region $i$ affecting the BC surface concentration (or climate forcing) in receptor region $j$ is defined as $\underline{15}$ 


$$
E F_{i, j}=\frac{C_{i, j}}{\mathrm{E}_{i}}
$$

where $\mathrm{C}_{\mathrm{i}, \mathrm{j}}$ is the fractional contribution to the aerosol property, and $\mathrm{E}_{\mathrm{i}}$ is the regional emission $(\mathrm{kg})$ in source region $I . \mathrm{EF}_{\mathrm{i}, \mathrm{j}}$ links the sensitivity of surface $\mathrm{BC}$ concentration in the receptor region $j$ to per unit emission in source region $i$. Thus, it is less dependent on the emission rates in the source regions and the total global emission rate.

\subsection{BC Direct Radiative Forcing}

To evaluate direct radiative forcing (DRF), the offline Rapid Radiative Transfer Model (RRTM) for general circulation models (GCMs), namely RRTMG, is adopted with a resolution of $1.9^{\circ} \times 2.5^{\circ}$. RRTMG has been widely applied and recognized for its use in climate models such as GFDL and NCAR (http://rtweb.aer.com/rrtm_frame.html). Using tagged BC concentration derived from MOZART-4, this study calculates the clear-sky DRF based upon perturbations of radiative fluxes by $\mathrm{BC}$ at the top-of-atmosphere (TOA) comparing with a zero-BC base case. RRTM retains the highest accuracy relative to line-by-line results for single column calculations, while RRTMG shares the same basic physics and absorption coefficients with RRTM and provides better efficiency with minimal loss of accuracy for GCM applications. The aerosol optical properties are defined and described by Ghan and Zaveri, $\underline{59}$ which showed the parameterization of optical properties for hydrated internally mixed aerosol and evaluated the parameterization by comparing with Mie solutions $\underline{60}$ for ammonium sulfate, black carbon, and a 50:50 mixture for a wide range in size distributions and relative humidity.

\subsection{Multiregional input-output model}

Production-based emissions are the regional emissions on the basis of geographic origin, i.e., where these emissions are released in the production process. 61 Consumption-based emissions attribute emissions to the region where emissions are

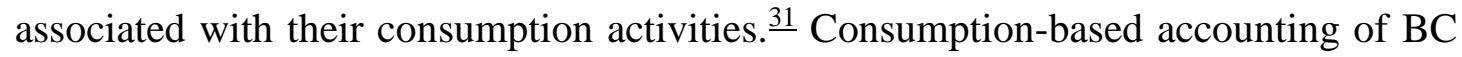


emissions differs from production-based inventories because of imports and exports of goods and services that, either directly or indirectly, involve BC emissions. The BC emissions embodied in imports and exports are referred to virtual transport of $\mathrm{BC}$ emissions in this study. In this study, we first build a production-based BC emission inventory ( $\mathrm{FPr}_{\mathrm{Pr}}$ ) for 129 countries/regions (Table S2) and 57 industry sectors (Table S3). The highly-resolved sectoral emission inventory is in line with the emission inventory with high spatial resolution used in the MOZART-4 model. The mapping of spatial emission inventory to sector-based emission inventory is shown in Table S4. Thereafter, we use a multiregional input-output (MRIO) analysis to evaluate the emissions embodied in international trade by allocating the total direct and indirect emissions generated in producing consumer goods for countries and industry sectors according to the final demand of consumers (consumption-based emission inventory) ${ }^{31}$. It should be noted that we trace all emissions associated with consumed goods back to the original source that generated the emissions even if the products were intermediate constituents in a multiregional supply chain or were transhipped through other countries/regions. Herein, we identify the $\mathrm{BC}$ emissions outsourced through international trade in manufactured products and services in 57 economic sectors.

MRIO analysis is emerging as a way to link final demand to the associated environmental pressures around the world against the background of globalization and the recent focus on lifecycle assessment $\underline{62}$. The MRIO table covers the entire economic structure of multiple regions, multiple sectors, exports and imports within and outside these regions as well as the intricate global supply chain. $\underline{63}$ Under this framework, the total direct and indirect emissions generated in producing consumed goods cover the entire supply chain and attribute the emissions from producers to the final consumers. $\underline{64}$ The MRIO enables identification of where the emissions embodied in final products initiated. $. \underline{65}, \underline{66}$ For example, emissions related to components manufactured in India that become part of a product assembled in China and ultimately exported to North America are assigned to the virtual transport of emissions from North America to India. These results can provide insights into the international cooperation to reduce the impact of long-range BC transport. 
For the entire economy with $m$ producers, we have

$$
\left(\begin{array}{c}
\mathbf{X}^{1} \\
\mathbf{X}^{2} \\
\mathbf{X}^{3} \\
\vdots \\
\mathbf{X}^{m}
\end{array}\right)=\left(\begin{array}{ccccc}
\mathbf{A}^{11} & \mathbf{A}^{12} & \mathbf{A}^{13} & \cdots & \mathbf{A}^{1 m} \\
\mathbf{A}^{21} & \mathbf{A}^{22} & \mathbf{A}^{23} & \cdots & \mathbf{A}^{2 m} \\
\mathbf{A}^{31} & \mathbf{A}^{32} & \mathbf{A}^{33} & \cdots & \mathbf{A}^{3 m} \\
\vdots & \vdots & \vdots & \ddots & \vdots \\
\mathbf{A}^{m 1} & \mathbf{A}^{m 2} & \mathbf{A}^{m 3} & \cdots & \mathbf{A}^{m m}
\end{array}\right)\left(\begin{array}{c}
\mathbf{X}^{1} \\
\mathbf{X}^{2} \\
\mathbf{X}^{3} \\
\vdots \\
\mathbf{X}^{m}
\end{array}\right)+\left(\begin{array}{c}
\sum_{s} \mathbf{Y}^{1 r} \\
\sum_{s} \mathbf{Y}^{2 r} \\
\sum_{s} \mathbf{Y}^{3 r} \\
\vdots \\
\sum_{s} \mathbf{Y}^{m r}
\end{array}\right)
$$

225 where $\mathbf{X}^{r}$ is a vector of the total economic output of region $r, \mathbf{Y}^{q r}$ is the final demand of region $r$ for goods produced in region $q ; \mathbf{A}^{q r}$ is a normalized matrix of intermediate consumption, reflecting the input from sectors in region q required to produce one unit of output from each sector in region $r$. Each sub-matrix $\mathbf{A}^{q r}$ is constructed by splitting bilateral trade data from GTAP V9.0 (in 2011) into components satisfying intermediate and final demand. This is achieved by using the input-output relationships of imports to region $r$, distributed according to the share of all imports to region $r$ made up of exports from $q$.

From this framework, the $\mathrm{BC}$ emissions embodied in products from region $\mathrm{q}$ to region $r$ is calculated as follows $\frac{67}{}$ :

$$
\mathbf{F}^{q r}=\tilde{\mathbf{h}}^{\mathrm{q}} \tilde{\mathbf{h}}^{\mathrm{q}}(\mathbf{I}-\mathbf{A})^{-1} \mathbf{Y} \cdot r \cdot r
$$

where $\mathbf{F}^{q r}$ represents the total embodied BC emission flow from region $q$ to region $r$;

$\tilde{\mathbf{h}}^{\mathrm{q}}$ is a vector of the corresponding direct emission intensity for region $q$ but zero for all other regions; $\mathbf{Y}^{\cdot}{ }^{r}$ is the final demand vector of region $r$.

We use the following indicators to measure source-receptor relationships between producers and consumers and to quantify the influence efficiency of consumers in region $i$ affecting $\mathrm{BC}$ emissions in region $j$, where the production activities occur.

The fraction contribution of consumers in region $i$ to $\mathrm{BC}$ emission in region $\mathrm{j}, \mathrm{D}_{\mathrm{i}, \mathrm{j}}$, is defined as

$$
D^{i, j}=\frac{F^{i, j}}{F^{j}}
$$

where $F^{\mathrm{ij}}$ is the $\mathrm{BC}$ emission change in region $\mathrm{j}$ due to consumption in region $i$, and $\mathrm{F}^{\mathrm{j}}=\sum_{i=1}^{N} F^{i, j} F^{i, j}$ represents the $\mathrm{BC}$ emission from all $\mathrm{N}=13$ consumer regions. 
defined as

$$
E F^{i, j}=\frac{D^{i . j}}{\operatorname{Con}^{i}}
$$

where $D^{\mathrm{i}, \mathrm{j}}$ is the fractional contribution to the aerosol property (i.e., surface concentration and radiative forcing) and $\mathrm{Con}^{i}$ is the final consumption in consumer region $i . E F^{i, j}$ links the $\mathrm{BC}$ emission in production region $j$ to per unit final consumption in region $i$. Thus, it is less dependent on the final consumption in the source regions and on the total global final consumption.

By integrating the effect of atmospheric transport and trade, we can quantify the efficiency of consumer region $i$ in affecting the BC property in region $j . I C^{i, j}$ is defined as

$$
I C^{i, j}=\frac{\sum_{k}^{N} C^{k, j} \times D^{i, k}}{\operatorname{Con}^{i}}
$$

$I C^{i, j}$ reflects the $\mathrm{BC}$ property in region $j$ caused by $\mathrm{BC}$ emissions globally, i.e., emitted in any region $(\mathrm{k}, \mathrm{k} \in 13)$ which are related to unit consumption of region $i$. For example, the emissions in India, Africa, etc $(k)$ related to final consumption of the USA $(i)$, which are finally transported in to East Asia (j). The definition of $C, D$ and $C o n$ are the same with equation (1) and (6).

\section{Results}

\subsection{BC concentration linked to producers and consumers}

Figure 1 highlights the key patterns of influence for physical BC transport from the emission sources to the downwind regions (Figure 1 Top), virtual BC transport from final consumers to the emitters via international trade (Figure 1 Middle), and the combined effect of physical and virtual $\mathrm{BC}$ transport from final consumers to the polluted regions (Figure 1 Bottom). The physical transport of $\mathrm{BC}$ is modulated by global atmospheric circulation, as well as by the location and intensity of emissions, the transport timescales, and the deposition rates of $\mathrm{BC}$. In the mid-latitudes of the northern 
hemisphere, the general atmospheric circulation is dominated by westerly wind, which facilitates trans-Pacific, trans-Atlantic and trans-Eurasian transport $\underline{\underline{68}}$. In most regions, surface $\mathrm{BC}$ concentrations are typically affected by the upwind western regions. For example, nearly $28 \%$ and $61 \%$ of the surface BC concentration in the former Soviet Union $\left(0.064 \mu \mathrm{g} \cdot \mathrm{m}^{-3}\right)$ and Middle Asia $\left(0.087 \mu \mathrm{g} \cdot \mathrm{m}^{-3}\right)$, respectively, were contributed by transboundary transport. Remarkably, the Middle East was responsible for 0.037 $\mu \mathrm{g} \cdot \mathrm{m}^{-3}(17.71 \%)$ surface BC concentrations in Mid-Asia. Europe contributed 0.026 $\mu \mathrm{g} \cdot \mathrm{m}^{-3}(25.9 \%)$ of the surface BC concentration in Mid-Asia. The two largest transboundary transports were from Africa to Middle East $\left(0.047 \mu \mathrm{g} \cdot \mathrm{m}^{-3}\right)$ and from India to Southeast Asia $\left(0.042 \mu \mathrm{g} \cdot \mathrm{m}^{-3}\right)$.

Virtual transport via trade has the opposite direction compared to the trade of products. When a country imports product from another country, it induces emissions and pollution in the exported country. Thus, the country imports products but exports emissions (virtual) to its trade partner. We find that the virtual flow from final consumers to emitters has a similar pattern as that of the atmospheric transport from developed regions such as North America and Europe in the west to the developing regions (East Asia and India) in the east. These emissions were embodied in products such as Petroleum, coal products, Chemical, rubber, plastic products and Machinery and equipment (Figure S3). A total of 26\%, 27\%, 17\% and 13\% of the industrial BC emissions in the former Soviet Union, Africa, East Asia, and India, respectively, were related to the production of exported goods or services for final consumers elsewhere.

The combined effect of physical and virtual transport from final consumers to the polluted regions is also from developed to developing regions, in the same direction as the westerlies in the northern hemisphere. In almost all cases, the influence of virtual transport embodied in trade is orders of magnitude larger than that of physical transport. For example, the consumption of Europe and North America contributed to 0.029 and $0.026 \mu \mathrm{g} \cdot \mathrm{m}^{-3}$ of the surface BC concentration in East Asia, which were 10 and 217 times the $\mathrm{BC}$ contributions physically originating from Europe and North America, respectively. Similarly, East Asia's consumption has a much larger impact on the surface $\mathrm{BC}$ concentrations in the Middle East, India and even the Southern Hemisphere 
303 than the physically transported $\mathrm{BC}^{\underline{23}}$.

304 
Figure 2 depicts the source of surface BC aerosols by tracing back to the emitters

(Figure 2 Upper) and to the final consumers of the related goods or services (Figure 2 Lower). From the viewpoint of the physical emitter, the BC surface concentrations were predominantly contributed by local emissions (Figure 2 Upper, for all regions except for Middle Asia, which is influenced largely by BC emissions transported its European neighbourhood). As part of the supply chain, local BC emissions generated by the production of exported goods or services also made a non-negligible contribution and were mainly driven by the final consumption in the U.S., Europe and East Asia. Approximately $4.2 \%$ and $4.7 \%$ of $\mathrm{BC}$ emissions in East Asia were contributed by consumption in the U.S. and Europe, while East Asia's consumption accounted for $4.2 \%$ and $2.7 \%$ of BC emissions in the U.S. and Europe. The absolute net virtual emission transfers were greatest among these three regions.

As for the complete supply chain, i.e., from the final consumers to the $\mathrm{BC}$ concentrations in each polluted region, the developed regions have larger contribution to the concentration in developing regions. China and India have the highest BC concentrations, and approximately $10 \%$ of these were contributed by consumers elsewhere. Emissions generated in other regions but driven by local consumption may flow back, but this portion (the grey bar in Figure S4) only contributed modestly to the local BC concentration, typically less than $1 \%$ for all regions except Middle Asia (3\%) 24. However, virtual transport via trade dominated the entire supply chain and was sometimes enhanced by atmospheric transport. This noticeable pattern reflects the fact that developed countries give rise to environmental pressures on emerging countries and generate additional pressures for less developed countries with lower environmental standards $s^{69}$. Developed countries have made considerable progress in reducing air pollutant emissions domestically but induce pollution emissions in developing countries $\underline{70}$. Efforts to improve energy efficiency and reduce end-of-pipe emissions may be partially counteracted if the virtual transport of air pollutants from foreign countries continues. Furthermore, East Asia also contributed to BC pollution in other regions (such as Africa and Southeast Asia) by importing raw materials such as oil and metals. Our results highlight the central role played by East Asia in the 
international supply chain, with a huge number of imports being processed for further export. Those efforts seeking to control transboundary air pollution should pay more attention to the virtual transport embedded in international trade.

\subsection{Interregional influence efficiency of $\mathrm{BC}$ pollution}

Assessing the influence efficiency also reveals the sensitivity of the polluted region to the production/consumption in another region. Figure 3 presents the influence efficiencies from consumers to emitters and ultimately to the polluted receptor regions. In most cases, the polluted region is the most sensitive to emission changes within that region. The interregional influence efficiencies were relatively small, except for the largest ones from Australia to Southeast Asia $\left(0.17 \mu \mathrm{g} \cdot \mathrm{m}^{-3} \cdot \mathrm{Tg}^{-1}\right)$, from Middle Asia to the former Soviet Union $\left(0.13 \mu \mathrm{g} \cdot \mathrm{m}^{-3} \cdot \mathrm{Tg}^{-1}\right)$ and from Middle East to India $\left(0.10 \mu \mathrm{g} \cdot \mathrm{m}^{-}\right.$ $\left.3 \cdot \mathrm{Tg}^{-1}\right)$.

The influence efficiency from final consumers to emitters is determined by trade structure, technology, energy efficiency and so on in the receiving regions. The influence efficiency of local consumption ranged from $0.0107 \mathrm{~g} \cdot \$^{-1}$ in Australia to $0.161 \mathrm{~g} \cdot \$^{-1}$ in India. Considering interregional influence efficiency, most regions were only sensitive to contiguous regions, with the highest efficiencies in terms of virtual transport being concentrated in several developing regions, such as East Asia and India. The BC emissions in East Asia and Europe were sensitive to the final demand of more than half of the regions in the world. In particular, in addition to its local consumption, East Asia was the most sensitive to the final demand of Southeast Asia $\left(0.0102 \mathrm{~g} \cdot \$^{-1}\right)$, Middle Asia $\left(0.0087 \mathrm{~g} \cdot \$^{-1}\right)$ and the Middle East $\left(0.0059 \mathrm{~g} \cdot \$^{-1}\right)$, which implies higher emission intensity of imports from East Asia (Figure S5)

$\mathrm{BC}$ concentration change at the receptor due to per unit final consumption $\left(\mu \mathrm{g} \cdot \mathrm{m}^{-}\right.$ ${ }^{3} \cdot \mathrm{Tg}^{-1} \cdot$ trillion $\left.\$^{-1}\right)$ in the source region reflects the influence efficiency of the complete supply chain, incorporating the atmospheric transport and virtual transport. The largest influence efficiencies were from Middle Asia to the former Soviet Union $(0.015 \mu \mathrm{g} \cdot \mathrm{m}$ 3.trillion $\left.\$^{-1}\right)$, from Middle East to India $\left(0.015 \mu \mathrm{g} \cdot \mathrm{m}-3 \cdot\right.$ trillion $\left.\$^{-1}\right)$, and from India to 
Southeast Asia $\left(0.0082 \mu \mathrm{g} \cdot \mathrm{m}-3 \cdot\right.$ trillion $\left.\$^{-1}\right)$. Overall, the interregional influence efficiencies between the former Soviet Union, Middle Asia, East Asia, Southeast Asia, and India were larger than others. Notably, per unit consumption in developing regions has larger influence on East Asia than the consumption in developed regions. East Asia should reduce energy intensity and improve export structure in the context of increasing final consumption in the above developing regions.

\subsection{Direct Radiative forcing (DRF) related to final consumers}

$\mathrm{BC}$ has dual roles in the environment due to its health effect and climate forcing function. While the surface BC concentration is associated with human health, DRF is used to reflect the climate forcing effect of BC. In this study, the simulated top-ofatmosphere direct radiative forcing (TOA DRF) is $0.275 \mathrm{Wm}^{-2}$, which is comparable to the previous estimates by Wang et al. $(0.17-0.31)^{\frac{71}{1}}$ and Schulz et al. $(0.27 \pm 0.06)^{\frac{72}{2}}$, slightly lower than the estimation in Bond et al. ${ }^{8}$ (Table S5). The difference is due to the modifications of the wet scavenging scheme in this study,, 17 Wang et al. and Schulz et al., which could match the HIPPO observations in a better way without sacrificing the consistency of other observations $\underline{17}, \underline{71}$. By using the MRIO and tagging technology, the inter-regional virtual transport of RF was characterized and shown in Figure 4.

Compared to the transport of surface concentration, the inter-regional contribution to DRF is slightly different since BC exerts enhanced DRF per unit of mass when transported to higher altitudes $\underline{73}, \underline{74}$. The contribution of local consumption for BC DRF ranges from $31.4 \%$ to $91.5 \%$ across all regions. The consumption of East Asia, North America exerted substantial forcing on other regions (row), especially on India, Middle East and South Africa. This pattern is consistent with previous findings $\frac{23}{}$. By using the tagging technology, we can obtain a source-receptor matrix, namely the contribution of imposed on each region that are associated with final consumption of goods locally or in other regions, as shown in Figure 4. Compared to previous studies, $\underline{22}, \underline{23}$ the BC DRF in Africa driven by other regions' final consumption was highlighted in this work. 
About $10 \%\left(0.01 \mathrm{Wm}^{-2}\right)$ of the total BC DRF in Africa (third column) were contributed by other regions' consumption, among which the DRF induced by consumption of Europe, North America and East Asia were 0.004, 0.002 and $0.002 \mathrm{Wm}^{-2}$, respectively. This is comparable to the total BC DRF in North America, Middle Asia, Australia, , Canada and the former Soviet Union.

The international trade extended the DRF imposed by Africa's final consumption. The $\mathrm{BC}$ emissions in $\mathrm{AF}$ were mainly transported to downwind regions (e.g., Middle East and Middle Asia) with atmospheric movement. Then the influence areas were extended to which South America and Australia due to virtual transport by trade. As the climate of Africa is characterized by a sensitive monsoon system that is subject to substantial global and regional changes in greenhouse-gas-induced, sea-level rise and substantial biomass burning $\frac{75}{}$. We argue that some attention should be paid to the emissions embodied in exports in Africa.

\section{Implications and uncertainties}

Transboundary air pollutants are attracting increasing attentions in recent years. A series of regional agreements has been created to address the problems associated with transboundary air pollutants, such as the Long-Range Transboundary Air Pollution (LRTAP) Convention ${ }^{76}$, the Acid Decomposition Monitoring Network in East Asia $(\text { EANET })_{\longrightarrow}^{77}$ and the Malé Declaration on Control and Prevention of Air Pollution $\underset{78}{ }$. Particularly, long-range transport of BC has attracted increasing attentions because of its climate effect in some critical regions (such as Arctic) $\underline{16}, \underline{17}, \underline{56}$. Increasing efforts have been made to explore the Arctic BC originating from the various major sources and the associated effect. The major gaps in the current literature are a failure to involve the virtual $\mathrm{BC}$ transport via trade. The results in this study indicates that considerable amount of $\mathrm{BC}$ emitted in China is also induced by final consumption in EU. The contribution to Arctic BC from EU would be more than acknowledged before if the supply chain from consumer to producer is included. Thus, the existing regional agreements considered the emitters of air pollution but overlooked the final consumers, 
which are the ultimate drivers initiating the production processes and may shift the emission by outsourcing the production. This may undermine the efforts to control transboundary air pollution, due partially to the competing effect between physical and virtual transport.

Increasing evidence has shown that polluting industries are tending to move to less-regulated regions where energy use efficiencies are low and emission intensities are much higher (Figure S6) $\underline{26}, \underline{79}, \underline{80}$. Emissions embodied in traded products in some emission-intensive sectors even amounted up to 65\% (e.g., metals nec) (Figure S7). For China, the emission intensity of Machinery and equipment is five times that in Europe and the U/S. However, almost half of the $\mathrm{BC}$ emissions outsourced to China was embodied in Machinery and equipment, which requires substantial inputs and production of metals, electricity, etc. Improving pollution control technologies in the production of coke, iron and steel, and electricity in China and facilitate technology transfer from developed regions would have disproportionately large environmental benefits at the regional and global scales. Figure S6 shows that there is great potential to improve the emission intensity in China. By furthering understanding of the supply chain for $\mathrm{BC}$, a global confederation of regional cooperative programmes in developing regions to eliminate the efficiency gap could help to develop a better, globally shared understanding of air pollution issues. Sharing responsibility is a promising way to facilitate international agreement on BC reductions towards the new warming mitigation framework following the Kyoto Protocol ${ }^{81}$.

The mitigation of aerosols driven by other regions is not a substitute for the emission reductions associated with locally produced goods used at the local and regional scale. For polluted regions, such as China, most air pollutants within the region are still associated with local consumption. However, a comprehensive understanding of all contributors of $\mathrm{BC}$ aerosols creates opportunities for other parties (e.g., final consumer) to participate in pollution abatement efforts alongside the emitters and local regulators. Otherwise, it is likely that many nations will be delayed in meeting their goals and objectives for protecting public health and environmental quality. 
451 (i.e., $\mathrm{SO}_{2}$, sulfate, mineral dust, $\mathrm{OC} 1$ and $\mathrm{OC} 2$ ) and the associated climate and health 452 effects is an important topic for future study. The other aerosols, although much harder to tag and quantify due to the complicated chemical processes, is also influenced by the proportion of a given region's consumption supplied via trade. The uncertainties propagated across multiple models are difficult to be quantified. However, validation of each model helps to ensure the robustness of our main findings. The uncertainties propagated across multiple models are difficult to quantify. However, validation of each model helps to ensure the robustness of our main findings. The uncertainty analysis of the production-based emission inventories used in this study were conducted using a Monte Carlo simulation. Variations in source strengths, emission factors, the efficiencies of control technologies, compliance rates, and coal ash content and fractions were all included. A detailed description of the major uncertainties in the production-based emission inventory can be found in our published papers $1, \underline{10}, \underline{82-84}$. Global BC emission from energy-related sources in this study is $\sim 30 \%$ higher than that in previous studies because of updated emission factors and the use of local fuel data. $\underline{30}$ The errors in the response in receptor regions to emissions change in the source regions are within $4 \% .{ }^{15}$ MRIO calculations contributed additional uncertainty which is inherent from national economic statistics and data harmonization $\frac{85}{}$. Moreover, intercomparison of different global MRIO databases showed that $\mathrm{CO}_{2}$ emissions embodied in international trade vary up to $13 \%$ and the observed differences among MRIO results were close to differences in underlying production-based inventories. $\underline{24}$, $\underline{86}$ It indicates that MRIO-related error is relatively small than the error in a productionbased emission inventory. The BC concentrations and DRF simulated by the MOZART and RRTMG are affected by errors in emission inventories and the transport processes in the models. This study reduces the uncertainty in these processes by improving parameterizations of the aging processes and using tagging technique to quantify the fractional contribution in source regions without perturbing the emissions. Given the wide range of optimized lifetime by source region, the $\mathrm{BC}$ concentrations is a little different from previous studies, most of which used the global average lifetime for all regions. However, the modelled surface concentration agreed well with the 
observations.

\section{Acknowledgements}

483 This work was supported by funding from the National Natural Science Foundation of 484 China under awards 41571130010, 41629501, 41671491, and 41390240, the National 485 Key Research and Development Programme of China 2016YFC0206202, 486 2016YFA0602604, the 111 Project (B14001), the UK Natural Environment Research 487 Council (NE/N00714X/1 and NE/P019900/1) and Economic and Social Research 488 Council (ES/L016028/1), British Academy Grant (AF150310) and the Philip 489 Leverhulme Prize.

490

\section{Additional information}

492 Supplementary information. The Supporting Information providing additional text, 493 tables, and figures supporting the main text is available in the online version of the 494 paper.

495 496

\section{Competing financial interests}

497

The authors declare no competing financial interest.

\section{References}

1. Meng, J.; Liu, J.; Guo, S.; Li, J.; Li, Z.; Tao, S., Trend and driving forces of Beijing's black carbon emissions from sectoral perspectives. J Clean Prod 2016, 112, Part 2, 1272-1281.

2. Andreae, M. O.; Crutzen, P. J., Atmospheric aerosols: Biogeochemical sources and role in atmospheric chemistry. Science 1997, 276, (5315), 1052-1058. PM2. 5. Environ. Sci. Technol. 2015, 49, (13), 8057-8066. pollution sources to premature mortality on a global scale. Nature 2015, 525, (7569), 367-371. 
the Associated Exposure. Springer: 2015.

6. Li, Z.; Liu, J.; Mauzerall, D. L.; Li, X.; Fan, S.; Horowitz, L. W.; He, C.; Yi, K.; Tao, S., A potential large and persistent black carbon forcing over Northern Pacific inferred from satellite observations. Scientific Reports 2017, 7, 43429.

7. Ramanathan, V.; Carmichael, G., Global and regional climate changes due to black carbon. Nat. Geosci. 2008, 1, (4), 221-227.

8. Bond, T. C.; Doherty, S. J.; Fahey, D.; Forster, P.; Berntsen, T.; DeAngelo, B.; Flanner, M.; Ghan, S.; Kärcher, B.; Koch, D., Bounding the role of black carbon in the climate system: A scientific assessment. Journal of Geophysical Research: Atmospheres 2013, 118, (11), 5380-5552.

9. Department of Environmental Protection A CLIMATE ACTION PLAN FOR MAINE 2004. http://maineghg.raabassociates.org/Articles/MaineClimateActionPlan2004Volume\%201.pdf; 2004.

10. Geng, F.; Hua, J.; Mu, Z.; Peng, L.; Xu, X.; Chen, R.; Kan, H., Differentiating the associations of black carbon and fine particle with daily mortality in a Chinese city. Environ. Res. 2013, 120, 27-32. 11. Wang, X.; Chen, R.; Meng, X.; Geng, F.; Wang, C.; Kan, H., Associations between fine particle, coarse particle, black carbon and hospital visits in a Chinese city. Sci. Total Environ. 2013, 458, 1-6. 12. Janssen, N. A. H.; Hoek, G.; Simic-Lawson, M.; Fischer, P.; van Bree, L.; ten Brink, H.; Keuken, M.; Atkinson, R. W.; Anderson, H. R.; Brunekreef, B.; Cassee, F. R., Black Carbon as an Additional Indicator of the Adverse Health Effects of Airborne Particles Compared with PM10 and PM2.5. Environ. Health Perspect. 2011, 119, (12), 1691-1699.

13. World Health Organization (WHO). Healtheffects of black carbon; 2012.

14. Zhang, Q.; He, K.; Huo, H., Policy: cleaning China's air. Nature 2012, 484, (7393), 161-162.

15. Wang, H.; Rasch, P. J.; Easter, R. C.; Singh, B.; Zhang, R.; Ma, P. L.; Qian, Y.; Ghan, S. J.; Beagley, N., Using an explicit emission tagging method in global modeling of source - receptor relationships for black carbon in the Arctic: Variations, sources, and transport pathways. Journal of Geophysical Research: Atmospheres 2014, 119, (22), 12,888-12,909.

16. Liu, J. F.; Fan, S. M.; Horowitz, L. W.; Levy, H. Evaluation of factors controlling long-range transport of black carbon to the Arctic. J. Geophys. Res. 2011, 116, D04307.

17. Zhang, J.; Liu, J.; Tao, S.; Ban-Weiss, G., Long-range transport of black carbon to the Pacific Ocean and its dependence on aging timescale. Atmos. Chem. Phys. 2015, 15, (20), 11521-11535.

18. Liu, J.; Mauzerall, D. L., Potential influence of inter-continental transport of sulfate aerosols on air 
quality. Environ. Res. Lett. 2007, 2, (4), 045029.

19. Derwent, R.; Stevenson, D.; Collins, W.; Johnson, C., Intercontinental transport and the origins of the ozone observed at surface sites in Europe. Atmos. Environ. 2004, 38, (13), 1891-1901.

20. Liu, J. F.; Mauzerall, D. L.; Horowitz, L. W.; Ginoux, P.; Fiore, A. M., Evaluating inter-continental transport of fine aerosols: (1) Methodology, global aerosol distribution and optical depth. Atmos. Environ. 2009, 43, (28), 4327-4338.

21. Meng, J.; Liu, J.; Xu, Y.; Guan, D.; Liu, Z.; Huang, Y.; Tao, S. In Globalization and pollution: teleconnecting local primary PM2. 5 emissions to global consumption, Proc. R. Soc. A, 2016; The Royal Society: 2016; p 20160380.

22. Zhang, Q.; Jiang, X.; Tong, D.; Davis, S. J.; Zhao, H.; Geng, G.; Feng, T.; Zheng, B.; Lu, Z.; Streets, D. G., Transboundary health impacts of transported global air pollution and international trade. Nature 2017, 543, (7647), 705-709.

23. Lin, J.; Tong, D.; Davis, S.; Ni, R.; Tan, X.; Pan, D.; Zhao, H.; Lu, Z.; Streets, D.; Feng, T., Global climate forcing of aerosols embodied in international trade. Nat. Geosci. 2016, 9, (10), 790-794.

24. Lin, J.; Pan, D.; Davis, S. J.; Zhang, Q.; He, K.; Wang, C.; Streets, D. G.; Wuebbles, D. J.; Guan, D., China's international trade and air pollution in the United States. Proc. Natl. Acad. Sci. 2014, 111, (5), 1736-1741.

25. Li, Y.; Meng, J.; Liu, J.; Xu, Y.; Guan, D.; Tao, W.; Huang, Y.; Tao, S., Interprovincial Reliance for Improving Air Quality in China: A Case Study on Black Carbon Aerosol. Environ. Sci. Technol. 2016, 50, (7), 4118-4126.

26. Zhao, H.; Zhang, Q.; Guan, D.; Davis, S.; Liu, Z.; Huo, H.; Lin, J.; Liu, W.; He, K., Assessment of China's virtual air pollution transport embodied in trade by using a consumption-based emission inventory. Atmos. Chem. Phys. 2015, 15, (10), 5443-5456.

27. Chen, L.; Meng, J.; Liang, S.; Zhang, H.; Zhang, W.; Liu, M.; Tong, Y.; Wang, H.; Wang, W.; Wang, X.; Shu, J., Trade-Induced Atmospheric Mercury Deposition over China and Implications for Demand-Side Controls. Environ. Sci. Technol. 2018, 52, (4), 2036-2045.

28. Takahashi, K.; Nansai, K.; Tohno, S.; Nishizawa, M.; Kurokawa, J.-i.; Ohara, T., Production-based emissions, consumption-based emissions and consumption-based health impacts of PM 2.5 carbonaceous aerosols in Asia. Atmos. Environ. 2014, 97, 406-415.

29. Nagashima, F.; Kagawa, S.; Suh, S.; Nansai, K.; Moran, D., Identifying critical supply chain paths 
and key sectors for mitigating primary carbonaceous $\mathrm{PM}_{2.5}$ mortality in Asia. Econ. Syst. Res. 2017, 29, (1), 105-123.

30. Wang, R.; Tao, S.; Balkanski, Y.; Ciais, P.; Boucher, O.; Liu, J.; Piao, S.; Shen, H.; Vuolo, M. R.; Valari, M., Exposure to ambient black carbon derived from a unique inventory and high-resolution model. Proc. Natl. Acad. Sci. 2014, 111, (7), 2459-2463.

31. Davis, S. J.; Caldeira, K., Consumption-based accounting of CO2 emissions. Proc. Natl. Acad. Sci. 2010, 107, (12), 5687-5692.

32. Li, J. S., Xia, X. H., Chen, G. Q., Alsaedi, A. and Hayat, T. "Optimal embodied energy abatement strategy for Beijing economy: Based on a three-scale input-output analysis". Renewable \& Sustainable Energy Reviews, 2016, 53:1602-1610.

33. Mi, Z.; Meng, J.; Guan, D.; Shan, Y.; Song, M.; Wei, Y.; Liu, Z.; Hubacek, K., Chinese CO2 emission flows have reversed since the global financial crisis. Nature communications 2017, 8, (1), 1712.

34. Yu, Y.; Feng, K.; Hubacek, K., Tele-connecting local consumption to global land use. Glob. Environ. Change 2013, 23, 1178-1186.

35. Weinzettel, J.; Hertwich, E. G.; Peters, G. P.; Steen-Olsen, K.; Galli, A., Affluence drives the global displacement of land use. Glob. Environ. Change 2013, 23, 433-438.

36. Chen, Z.-M.; Chen, G. Q., Demand-driven energy requirement of world economy 2007: A multiregion input-output network simulation. Commun Nonlinear Sci 2013, 18, (7), 1757-1774.

37. Wiedmann, T. O.; Schandl, H.; Lenzen, M.; Moran, D.; Suh, S.; West, J.; Kanemoto, K., The material footprint of nations. Proc. Natl. Acad. Sci. 2015, 112, (20), 6271-6276.

38. Chen, Z.-M.; Chen, G. Q., Virtual water accounting for the globalized world economy: National water footprint and international virtual water trade. Ecol. Indic. 2013, 28, (0), 142-149.

39. Feng, K.; Chapagain, A.; Suh, S.; Pfister, S.; Hubacek, K., Comparison of bottom-up and top-down approaches to calculating the water footprints of nations. Econ. Syst. Res. 2011, 23, (4), 371-385.

40. Lenzen, M.; Moran, D.; Bhaduri, A.; Kanemoto, K.; Bekchanov, M.; Geschke, A.; Foran, B., International trade of scarce water. Ecol. Econ. 2013, 94, 78-85.

41. Lenzen, M.; Moran, D.; Kanemoto, K.; Foran, B.; Lobefaro, L.; Geschke, A., International trade drives biodiversity threats in developing nations. Nature 2012, 486, (7401), 109-112.

42. Emmons, L.; Walters, S.; Hess, P.; Lamarque, J.-F.; Pfister, G.; Fillmore, D.; Granier, C.; Guenther, 
A.; Kinnison, D.; Laepple, T., Description and evaluation of the Model for Ozone and Related chemical Tracers, version 4 (MOZART-4). Geoscientific Model Development 2010, 3, (1), 43-67.

43. Rasch, P.; Mahowald, N.; Eaton, B., Representations of transport, convection, and the hydrologic cycle in chemical transport models: Implications for the modeling of short - lived and soluble species. Journal of Geophysical Research: Atmospheres (1984-2012) 1997, 102, (D23), 28127-28138.

44. Lin, S.-J.; Rood, R. B., Multidimensional flux-form semi-Lagrangian transport schemes. Monthly Weather Review 1996, 124, (9), 2046-2070.

45. Horowitz, L. W.; Walters, S.; Mauzerall, D. L.; Emmons, L. K.; Rasch, P. J.; Granier, C.; Tie, X.; Lamarque, J. F.; Schultz, M. G.; Tyndall, G. S., A global simulation of tropospheric ozone and related tracers: Description and evaluation of MOZART, version 2. Journal of Geophysical Research: Atmospheres (1984-2012) 2003, 108, (D24), 4784-4799.

46. Holtslag, A.; Boville, B., Local versus nonlocal boundary-layer diffusion in a global climate model. J Climate 1993, 6, (10), 1825-1842.

47. Hack, J. J., Parameterization of moist convection in the National Center for Atmospheric Research community climate model (CCM2). Journal of Geophysical Research: Atmospheres 1994, 99, (D3), $5551-5568$.

48. Zhang, G. J.; McFarlane, N. A., Sensitivity of climate simulations to the parameterization of cumulus convection in the Canadian Climate Centre general circulation model. Atmos. Ocean 1995, 33, (3), 407-446.

49. Chin, M.; Ginoux, P.; Kinne, S.; Torres, O.; Holben, B. N.; Duncan, B. N.; Martin, R. V.; Logan, J. A.; Higurashi, A.; Nakajima, T., Tropospheric aerosol optical thickness from the GOCART model and comparisons with satellite and Sun photometer measurements. Journal of the atmospheric sciences 2002, $59,(3), 461-483$.

50. Horowitz, L. W., Past, present, and future concentrations of tropospheric ozone and aerosols: Methodology, ozone evaluation, and sensitivity to aerosol wet removal. Journal of Geophysical Research: Atmospheres (1984-2012) 2006, 111, D22211.

51. Tie, X.; Madronich, S.; Walters, S.; Edwards, D. P.; Ginoux, P.; Mahowald, N.; Zhang, R.; Lou, C.; Brasseur, G., Assessment of the global impact of aerosols on tropospheric oxidants. Journal of Geophysical Research: Atmospheres (1984-2012) 2005, 110, D03204.

52. Wang, R.; Tao, S.; Ciais, P.; Shen, H.; Huang, Y.; Chen, H.; Shen, G.; Wang, B.; Li, W.; Zhang, Y., 
High-resolution mapping of combustion processes and implications for CO 2 emissions. Atmos. Chem. Phys. 2013, 13, (10), 5189-5203.

53. van der Werf, G. R.; Randerson, J. T.; Giglio, L.; Collatz, G.; Mu, M.; Kasibhatla, P. S.; Morton, D. C.; DeFries, R.; Jin, Y. v.; van Leeuwen, T. T., Global fire emissions and the contribution of deforestation, savanna, forest, agricultural, and peat fires (1997-2009). Atmos. Chem. Phys. 2010, 10, (23), 1170711735

54. Shindell, D.; Chin, M.; Dentener, F.; Doherty, R.; Faluvegi, G.; Fiore, A.; Hess, P.; Koch, D.; MacKenzie, I.; Sanderson, M., A multi-model assessment of pollution transport to the Arctic. Atmos. Chem. Phys. 2008, 8, (17), 5353-5372.

55. Yu, H.; Chin, M.; West, J. J.; Atherton, C. S.; Bellouin, N.; Bergmann, D.; Bey, I.; Bian, H.; Diehl, T.; Forberth, G., A multimodel assessment of the influence of regional anthropogenic emission reductions on aerosol direct radiative forcing and the role of intercontinental transport. Journal of Geophysical Research: Atmospheres 2013, 118, (2), 700-720.

56. Yang, Y.; Wang, H.; Smith, S. J.; Zhang, R.; Lou, S.; Qian, Y.; Ma, P.-L.; Rasch, P. J., Recent intensification of winter haze in China linked to foreign emissions and meteorology. Scientific reports 2018, 8, (1), 2107.

57. Yang, Y.; Wang, H.; Smith, S. J.; Ma, P.-L.; Rasch, P. J., Source attribution of black carbon and its direct radiative forcing in China. Atmos. Chem. Phys. 2017, 17, (6), 4319.

58. Li, Y.; Meng, J.; Liu, J.; Xu, Y.; Guan, D.; Tao, W.; Huang, Y.; Tao, S., Interprovincial Reliance for Improving Air Quality in China: A Case Study on Black Carbon Aerosol. Environ. Sci. Technol. 2016, 50, (7), 4118-4126.

59. Ghan, S. J.; Zaveri, R. A., Parameterization of optical properties for hydrated internally mixed aerosol. Journal of Geophysical Research: Atmospheres 2007, 112, D10201.

60. Mie, G., Beiträge zur Optik trüber Medien, speziell kolloidaler Metallösungen. Ann. Phys. 1908, 330, (3), 377-445.

61. Meng, J.; Liu, J.; Xu, Y.; Tao, S., Tracing Primary PM2. 5 emissions via Chinese supply chains. Environ. Res. Lett. 2015, 10, (5), 054005.

62. Wiedmann, T., A review of recent multi-region input-output models used for consumption-based emission and resource accounting. Ecol. Econ. 2009, 69, (2), 211-222.

63. Li J. S., Chen B., Chen G. Q., Wei W. D., Wang X. B., Ge J. P., Dong K. Q., Xia H. H. and Xia X. 
H. Tracking mercury emission flows in the global supply chains: A multi-regional input-output analysis. Journal of Cleaner Production, 2017, 140:1470-1492.

64. Peters, G. P.; Hertwich, E. G., Post-Kyoto greenhouse gas inventories: production versus consumption. Clim. Change 2008, 86, (1-2), 51-66.

65. Galli, A.; Weinzettel, J.; Cranston, G.; Ercin, E., A Footprint Family extended MRIO model to support Europe's transition to a One Planet Economy. Sci. Total Environ. 2013, 461-462, 813-8. 66. Feng, K. S.; Davis, S. J.; Sun, L. X.; Li, X.; Guan, D. B.; Liu, W. D.; Liu, Z.; Hubacek, K., Outsourcing CO2 within China. Proc. Nat. Acad. Sci. U.S.A. 2013, 110, (28), 11654-11659.

67. Peters, G. P.; Minx, J. C.; Weber, C. L.; Edenhofer, O., Growth in emission transfers via international trade from 1990 to 2008. Proc. Nat. Acad. Sci. U.S.A. 2011, 108, (21), 8903-8908.

68. Dentener, F.; Keating, T.; Akimoto, H., Hemispheric transport of air pollution. United Nations, ISBN 2010, 978-92.

69. Kissinger, M.; Rees, W. E., Importing terrestrial biocapacity: The US case and global implications. Land Use Policy 2010, 27, (2), 589-599.

70. Moran, D.; Kanemoto, K., Tracing global supply chains to air pollution hotspots. Environ. Res. Lett. 2016, 11, (9), 094017.

71. Wang, Q.; Jacob, D. J.; Spackman, J. R.; Perring, A. E.; Schwarz, J. P.; Moteki, N.; Marais, E. A.; Ge, C.; Wang, J.; Barrett, S. R., Global budget and radiative forcing of black carbon aerosol: Constraints from pole - to - pole (HIPPO) observations across the Pacific. Journal of Geophysical Research: Atmospheres 2014, 119, (1), 195-206.

72. Schulz, M.; Textor, C.; Kinne, S.; Balkanski, Y.; Bauer, S.; Berntsen, T.; Berglen, T.; Boucher, O.; Dentener, F.; Guibert, S., Radiative forcing by aerosols as derived from the AeroCom present-day and pre-industrial simulations. Atmos. Chem. Phys. 2006, 6, (12), 5225-5246.

73. Babu, S. S.; Moorthy, K. K.; Manchanda, R. K.; Sinha, P. R.; Satheesh, S.; Vajja, D. P.; Srinivasan, S.; Kumar, V., Free tropospheric black carbon aerosol measurements using high altitude balloon: do BC layers build "their own homes" up in the atmosphere? Geophys. Res. Lett. 2011, 38, (8), L08803.

74. Ban-Weiss, G. A.; Cao, L.; Bala, G.; Caldeira, K., Dependence of climate forcing and response on the altitude of black carbon aerosols. Clim. Dyn. 2012, 38, (5-6), 897-911.

75. Knippertz, P.; Evans, M. J.; Field, P. R.; Fink, A. H.; Liousse, C.; Marsham, J. H., The possible role of local air pollution in climate change in West Africa. Nature Climate Change 2015, 5, (9), 815-822. 
76. The United Nations Economic Commission for Europe (UNECE). Convention on Long-range Transboundary Air Pollution. http://www.unece.org/env/lrtap/lrtap_h1.html.

77. Acid Deposition Monitoring Network in East Asia. http://www.eanet.asia/.

78. Regional Resource Center for Asis and the Pacific. Malé Declaration on Control and Prevention of Air Pollution. http://www.rrcap.ait.asia/male.

79. Levinson, A.; Taylor, M. S., Unmasking the pollution haven effect. International economic review 2008, 49, (1), 223-254.

80. Kanemoto, K.; Moran, D.; Lenzen, M.; Geschke, A., International trade undermines national emission reduction targets: New evidence from air pollution. Glob. Environ. Change 2014, 24, 52-59.

81. Oberthür, S.; Ott, H. E., The Kyoto Protocol: international climate policy for the 21st century. Springer Science \& Business Media: 1999.

82. Huang, T.; Zhu, X.; Zhong, Q.; Yun, X.; Meng, W.; Li, B.; Ma, J.; Zeng, E. Y.; Tao, S., Spatial and Temporal Trends in Global Emissions of Nitrogen Oxides from 1960 to 2014. Environ. Sci. Technol. 2017, 51(14): 7992-8000.

83. Meng, W.; Zhong, Q.; Yun, X.; Zhu, X.; Huang, T.; Shen, H.; Chen, Y.; Chen, H.; Zhou, F.; Liu, J., Improvement of a Global High-Resolution Ammonia Emission Inventory for Combustion and Industrial Sources with New Data from the Residential and Transportation Sectors. Environ. Sci. Technol. 2017, $51,(5), 2821-2829$.

84. Huang, Y.; Shen, H.; Chen, Y.; Zhong, Q.; Chen, H.; Wang, R.; Shen, G.; Liu, J.; Li, B.; Tao, S., Global organic carbon emissions from primary sources from 1960 to 2009. Atmos. Environ. 2015, 122, 505-512.

85. Wiedmann, T.; Wilting, H. C.; Lenzen, M.; Lutter, S.; Palm, V., Quo Vadis MRIO? Methodological, data and institutional requirements for multi-region input-output analysis. Ecol. Econ. 2011, 70, (11), 1937-1945.

86. Peters, G. P.; Davis, S. J.; Andrew, R., A synthesis of carbon in international trade. Biogeosciences 2012, 9, (8), 3247-3276.

\section{Figures}






Fig. 1| Geographical supply chain of global BC aerosol. Surface BC concentrations contributed by emitters to downwind regions ( $a$, the colour of a region indicates its annual mean surface BC concentration, and arrows indicate surface $\mathrm{BC}$ contributions); virtual $\mathrm{BC}$ transport via international trade (arrows) from final consumers to emitters ( $b$, the colour of a region represents the difference between exported and imported emissions, or the net emission transfer; note that virtual $\mathrm{BC}$ transport via trade has a direction opposite to that for the trade of products—when a country imports products from another country, it means that it exports emissions to that country); and combined physical and virtual transport from final consumers to the polluted region $(c$, colours indicate the surface $\mathrm{BC}$ concentrations). The width of the arrow reflects the relative contributions. 


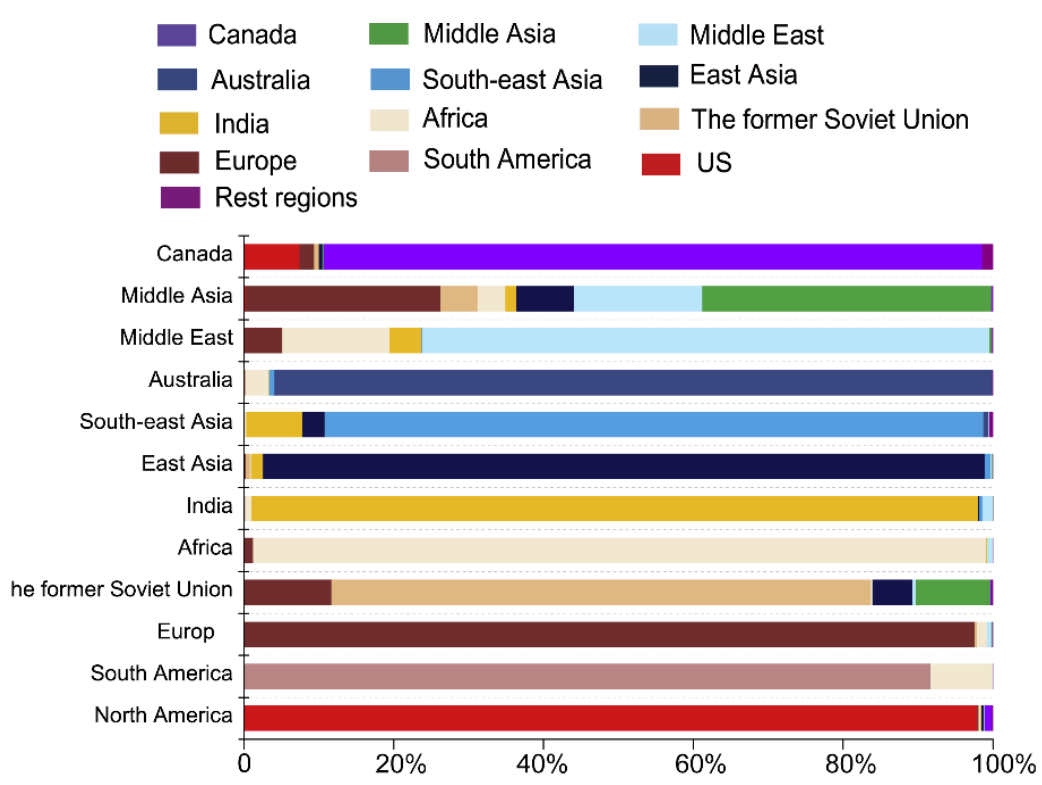

(a) Contribution of emitter

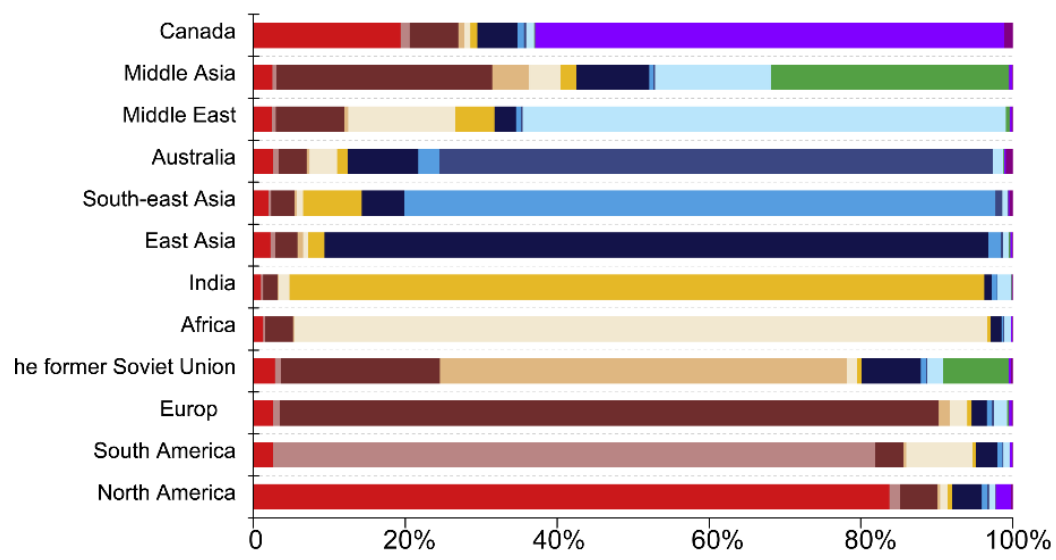

(b) Contribution of final consumption

730 Fig. 2| Geographical sources of $\mathrm{BC}$ emissions for selected regions. (a) regional contributions to

731 local BC concentration from view of where the BC aerosols are physically emitted. (b) regional 732 contributions to local $\mathrm{BC}$ concentration from view of where the goods and services related to the 733 surface $\mathrm{BC}$ concentrations are ultimately consumed. 
(a) Influence Efficiency of Atmospheric Transport ( $\mu \mathrm{g} \cdot \mathrm{m}-3 \cdot \mathrm{Tg}-1)$
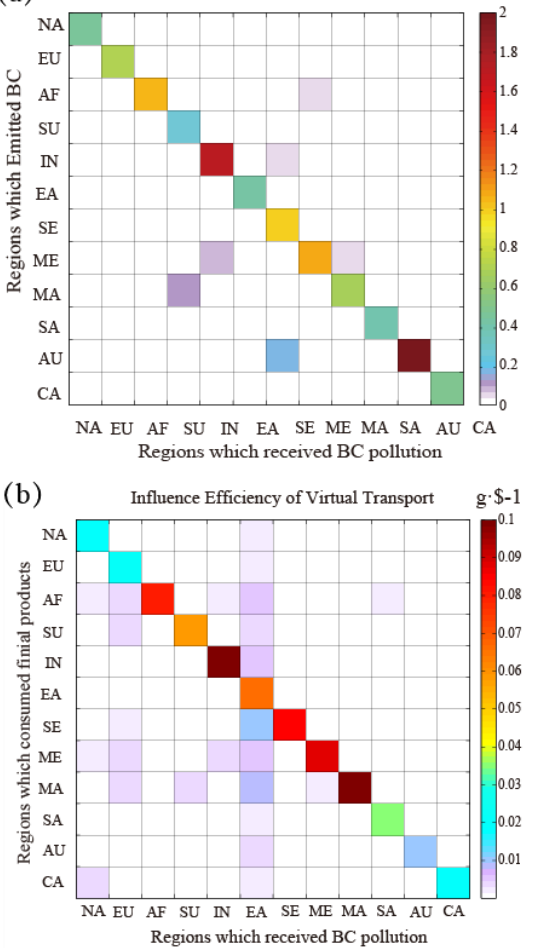

(c) Influence Efficiency of Combined Effect $(\mu \mathrm{g} \cdot \mathrm{m}-3 \cdot$ trillion $\$-1)$

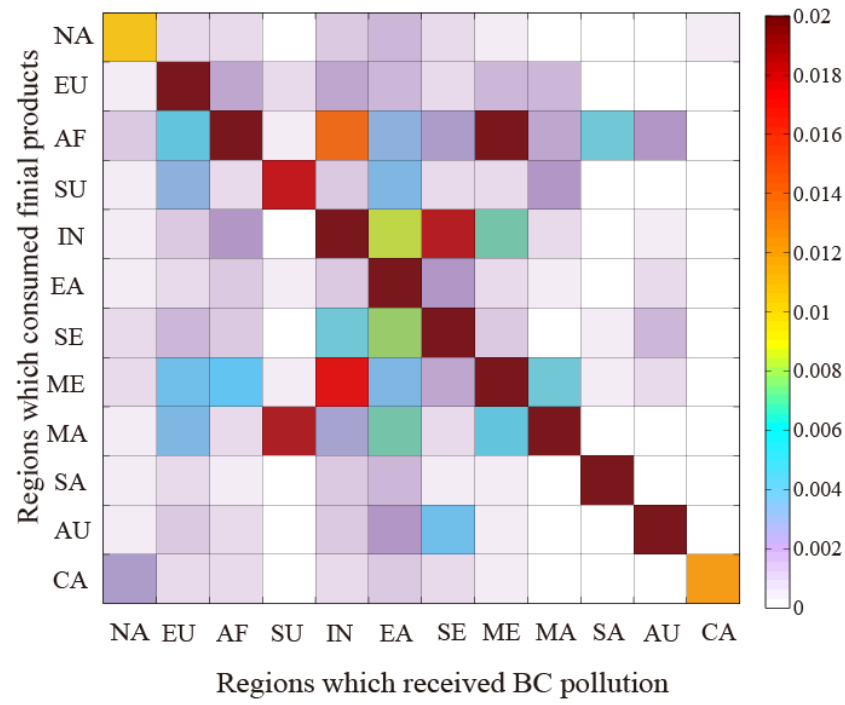

Fig. 3| The interregional influence efficiency of BC pollution in the global supply chain: (a)

738 atmospheric transport from regions which emitted BC to the receiving regions $\left(\mu \mathrm{g} \cdot \mathrm{m}^{-3} \cdot \mathrm{Tg}^{-1}\right)$; (b)

739 virtual relocation of $\mathrm{BC}$ emissions from final consumers to regions which emitted $\mathrm{BC}\left(\mathrm{g} \cdot \$^{-1}\right)$; (c)

740 combined physical and virtual transport of $\mathrm{BC}$ pollution from final consumers to each receptor

741 region $\left(\mu \mathrm{g} \cdot \mathrm{m}^{-3} \cdot \mathrm{Tg}^{-1} \cdot \operatorname{trillion} \$^{-1}\right)$. 
Regions where forcing were imposed

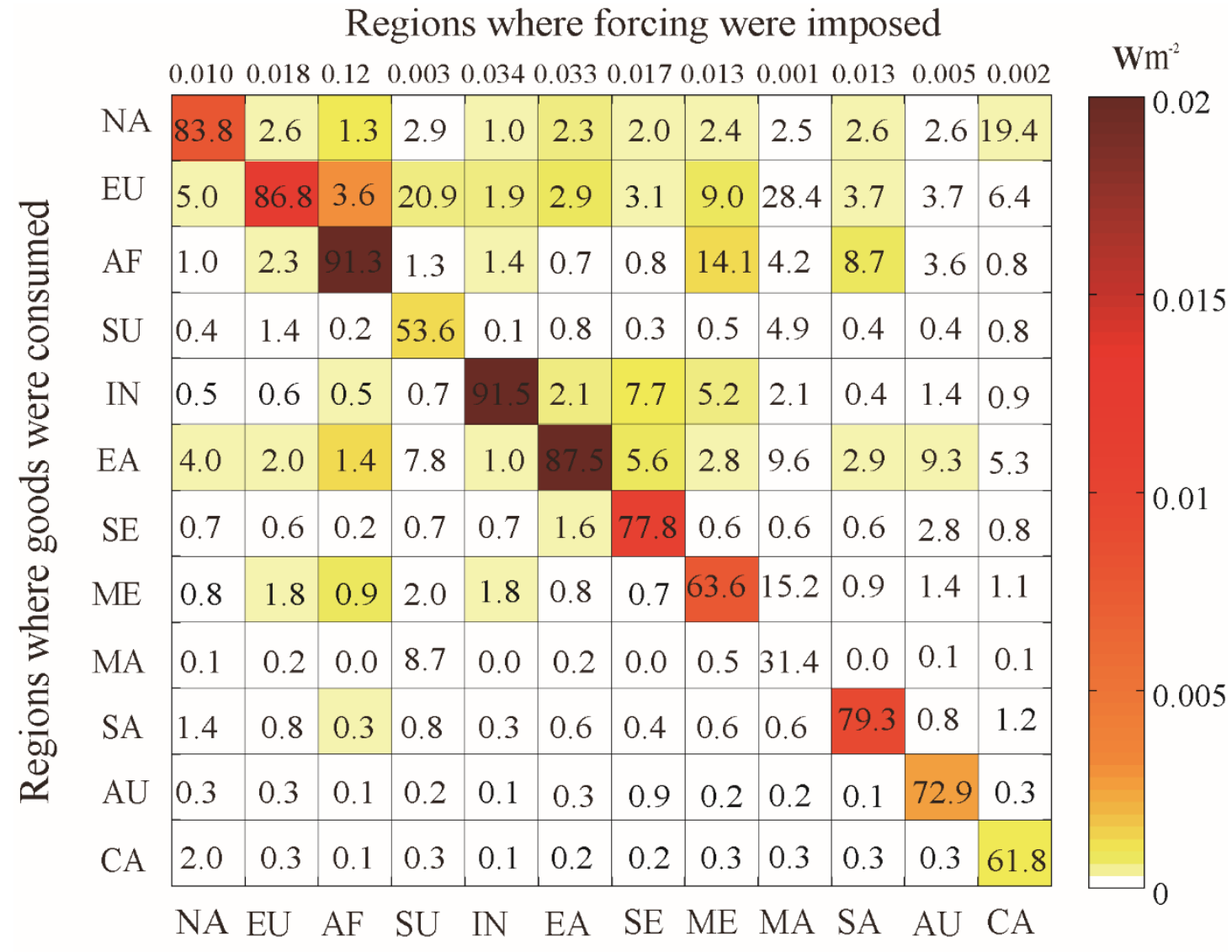

Figure 4 | Radiative forcing of $\mathrm{BC}$ in a given region that are linked to goods and services

consumed in that and other regions. Each cell in the grid shows the radiative forcing (RF) of BC

in the region indicated by the column due to pollution related to goods and services consumed in the region indicated by the row. The diagonal thus reflects radiative forcing in a region due to goods and services consumed locally. The colour shading indicates the value of RF while the number in each grid is the proportion of $\mathrm{RF}$ in the region (\%). The total $\mathrm{RF}$ of $\mathrm{BC}$ in each region is shown at the top. 